\title{
Vibrio parahaemolyticus in marine foods of animal origin from establishments in the port of Celestun, Yucatan, Mexico
}

DOI: $10.46932 / \mathrm{sfjdv2n2-015}$

Received in: january 1st, 2020

Accepted in: March 30th, 2020

\author{
José Franco-Monsreal \\ Doctor en Ciencias Médicas \\ E-mail: jose.franco@uimqroo.edu.mx \\ Alicia May-Panti \\ Licenciada en Salud Comunitaria \\ E-mail: alicia.may@uimqroo.edu.mx \\ Lidia Esther del Socorro Serralta-Peraza \\ Maestra en Educación \\ E-mail: lidia.serralta@uimqroo.edu.mx; \\ María Selene Sánchez-Uluac \\ Maestra en Ciencias \\ E-mail: selene.sanchez@uimqroo.edu.mx
}

\begin{abstract}
Introduction. The marine environment occupies practically three-quarters of the earth's surface and in coastal areas it is directly or indirectly related to man. Objective. To determine if seafood represents potential risk factors for Vibrio parahaemolyticus species for the development of acute gastroenteritis, wound infection, ear infection and secondary septicemia. Material and methods. A list of establishments specialized in the sale of seafood for human consumption was obtained. The amount of seafood in these establishments was 196. Results. In 13 (3.33\%) samples an equal number of strains were isolated whose biochemical characteristics corresponded to the species Vibrio parahaemolyticus. Conclusion. Raw seafood and partially heat-cooked seafood represents potential risk factors for Vibrio parahaemolyticus species for the development of acute gastroenteritis, wound infection, ear infection, and secondary septicemia.
\end{abstract}

Keywords: Vibrio parahaemolyticus, seafood, establishments.

\section{INTRODUCTION}

Vibrio parahaemolitycus is a halophilic microorganism frequently found in seawater deposited on the seabed during winter. Above $14^{\circ} \mathrm{C}$ it leaves the sediment and parasitizes the zooplankton from where it is ingested by fish and shellfish. Acute diarrhea is due to ingestion of raw or undercooked fish and shellfish. It is typical of countries where raw fish is included as food, such as Japan. Symptoms include 
abdominal cramps, nausea, vomiting, headaches, and fever (https://www.elsevier.es/es-revista-offarm4-articulo-infecciones-gastrointestinales-13061801).

Vibrio parahaemolyticus is a human pathogen that is widely distributed in marine environments. This organism is frequently isolated from a variety of raw seafood, particularly shellfish. Consuming raw or undercooked shellfish contaminated with Vibrio parahaemolyticus can lead to the development of acute gastroenteritis characterized by diarrhea, headache, vomiting, nausea, and abdominal cramps. It has also been isolated from wound infection and septicemia. Most cases are not fatal. This bacterium is recognized as the leading cause of human gastroenteritis associated with shellfish consumption in the United States of America and a major shellfish-borne pathogen throughout the world. Chile faced its first outbreak in 1997-1998. Subsequently, outbreaks and cases have continued. All associated with the consumption of seafood (https://www.achipia.gob.cl/wp-content/uploads/2018/03/Ficha-Peligro-08-Vibrio-parahv01.pdf).

In the second edition of the Bergey Manual of Systematic Bacteriology the Family Vibrionaceae belongs to Order XI (Vibrionales) of Class III (Gammaproteobacteria) of the Phylum BXII (Proteobacteria) of the Bacteria Domain. In turn, the Vibrionaceae Family is made up of the Vibrio, Allomonas, Catenococcus, Enterovibrio, Grimontia, Listonella, Photobacterium and Salinivibrio genera. Twelve of the 66 species of the genus Vibrio are considered human pathogens and are Vibrio alginolyticus, Vibrio carchariae, Vibrio cholerae, Vibrio cincinnatiensis, Vibrio damsela, Vibrio fluvialis, Vibrio furnissii, Vibrio hollisae, Vibrio metschnikovii, Vibrio mimicus, Vibrio parahaemolyticus and Vibrio vulnificus (Garrity et al., 2004).

Vibrios are characteristically indigenous to marine, brackish, and estuarine habitats, and appear in high concentrations when water temperatures rise $\left(17-20^{\circ} \mathrm{C}\right)$. At low temperatures, the vibrios remain in the sediment of the seabed and the counts are usually lower than those necessary to cause infection. In temperate countries, vibrios are present in seawater throughout the year, although their concentration undergoes a notable increase in the warm months due to favorable ecological conditions and plankton, increasing their accumulation by filter feeders and other marine animals (West, 1989).

The hemolytic activity of most strains of human origin (Kanagawa toxin) has been demonstrated, as well as their capacity for enterotoxin production and for inflammation of the intestinal mucosa. The Kanagawa phenomenon is presented by the strains of Vibrio parahaemolyticus that possess TDH (heat stable direct hemolysin) and that is observed as a $\beta$-hemolysis in Wagatsuma agar. The strains that present this hemolysin grown on Wagatsuma agar containing human erythrocytes are hemolytic ( $\beta$-hemolysis, this fact is known as the Kanagawa phenomenon or test; epidemiological studies reveal a strong association between this phenomenon and gastroenteritis (Shirai et al., 1990). Three and 10 of a series of 
13 cases described in Denmark were, respectively, wound infections and ear infections (Hornstrup \& Gahm, 1993). After consumption of oysters, a woman suffered cardiogenic shock with previous diarrheal symptoms and abdominal pain (Tsujimoto et al., 1994). Vibrio parahaemolyticus is associated with acute gastroenteritis, wound infection, ear infection, and secondary septicemia (Pavia et al., 1989).

The causes that most frequently contribute to the occurrence of cases and outbreaks in the population include the consumption of raw seafood, seafood marinated without heat, seafood partially cooked with heat, and seafood fully cooked with heat; the defective or absent refrigeration that favors the multiplication of the microorganism; improper handling of food in kitchens which leads to cross contamination (Bryan, 1978); and contamination of seafood by the handler through the anus-hand-food mechanism because it is an asymptomatic carrier (Franco \& Flores, 1988).

According to their method of preparation, seafood was classified as raw, marinated without heat, partially cooked with heat, and fully cooked with heat. There were three varieties (crustaceans, mollusks and fish) and forty-two species studied (catfish, bosh or curucó; balá or whip ray, sea bream, boquinete, squid, shrimp, crab, snail, carp, tripe dogfish, cherna pinta, chopa, chucumite, cuddly, sea bass, cuberita, smedregal, black finned mackerel, crab, black horse mackerel, smooth, longtail, largemouth bass, manta ray, mussel, grouper, white mojarra, carp mojarra, tilapia mojarra, oyster, string pompano, mulatto snapper, pejelagarto, wahoo, octopus, ray, snook, blonde villajaiba, salmon, sierra, tilapia and white trout).

The objective of the present investigation was to determine the prevalence of the Vibrio parahaemolyticus species in raw seafood, marinated without heat, partially cooked with heat and fully cooked with heat. In other words, determine if raw seafood, non-heat marinated seafood, partially heatcooked seafood, and fully heat-cooked seafood represent potential risk factors for the species Vibrio parahaemolyticus for the development of acute gastroenteritis, wound infection, ear infection and secondary septicemia (Pavia et al., 1989).

Null hypothesis $\left(\mathbf{H}_{0}\right)$. Raw seafood, non-heat marinated seafood, partially heat-cooked seafood, and fully heat-cooked seafood are not contaminated by Vibrio parahaemolyticus.

Alternative hypothesis $\left(\mathbf{H}_{1}\right)$. At least one of the four methods of preparing seafood is contaminated by the species Vibrio parahaemolyticus.

\section{MATERIAL AND METHODS}

\subsection{EPISTEMOLOGICAL APPROACH}

Quantitative approach, probabilistic approach or positivist approach (Hernández et al., 2006). 


\subsection{STUDY DESIGN}

Descriptive, cross-sectional observational study without directionality and with prospective temporality (Hernández-Ávila, 2007).

\subsection{STUDY UNIVERSE}

The study was carried out in the total of samples of the 21 establishments specialized in the sale of seafood for human consumption in the port of Celestun, Yucatán, Mexico, in the period from June 1, 2017 to May 31, 2018. Celestun, Yucatán, México (Figure 1). Eco-tourist paradise in the state of Yucatán. Its exceptional landscape is part of the world heritage of the special biosphere reserve of the same name; with an area of 59,139 ha and a length of $21 \mathrm{~km}$, officially declared a wildlife refuge since 1979. Among its natural attractions are the Baldiosera spring to the east, where you can swim and dive; There is also the Cambay spring which is a spring of fresh water and finally there is Tambor where the main attraction is the pink or Caribbean Flamingo, the only known population in North America and which has the Celestun estuary as a feeding and resting point; Celestun flamingos are the pinkest in the world due to the concentration of carotene in the water. They can be observed in their natural ecosystem aboard boats guided by locals. To the east is the Real de Salinas ranch, a former salt extraction emporium. It also has the extraordinary, petrified forest called Tampetén and Punta Ninum where clams and miniature shrimp abound. At the edge of the route, you can find a great diversity of flora and fauna of special beauty, ducks that emigrate from Canada and that arrive at the estuary in the months that go from December to March, a great variety of fish, pelicans, herons, albatrosses. and other aquatic birds that inhabit a lowland deciduous forest and tropical savanna ecosystem. Here you can also see 234 different species of mammals that inhabit the estuary; among the main ones are the ocelot, jaguar, tigrillo and the spider monkey, which are considered endangered species along with three species of sea turtles and two of crocodiles. Its inhabitants have always dedicated themselves to fishing (grouper, dogfish, corvina, pámpano, octopus and many others) and the exploitation of salt flats. $31 \mathrm{~km}$. North of Celestun, along a coastal dirt road, is located El Palmar, one of the most important ecological reserves, where migratory waterfowl such as the Canadian duck live, and it is an ideal destination for the practice of ecotourism. Another important attraction is its huge lighthouse, considered the highest in the State. Celestun is located west of the state of Yucatán, 109 km from Mérida and 123 km west of the City and Port of Progreso de Castro, Yucatán, México (http://www.yucatan.gob.mx/?p=celestun). 
Figure 1. Celestun, Yucatán, Mexico

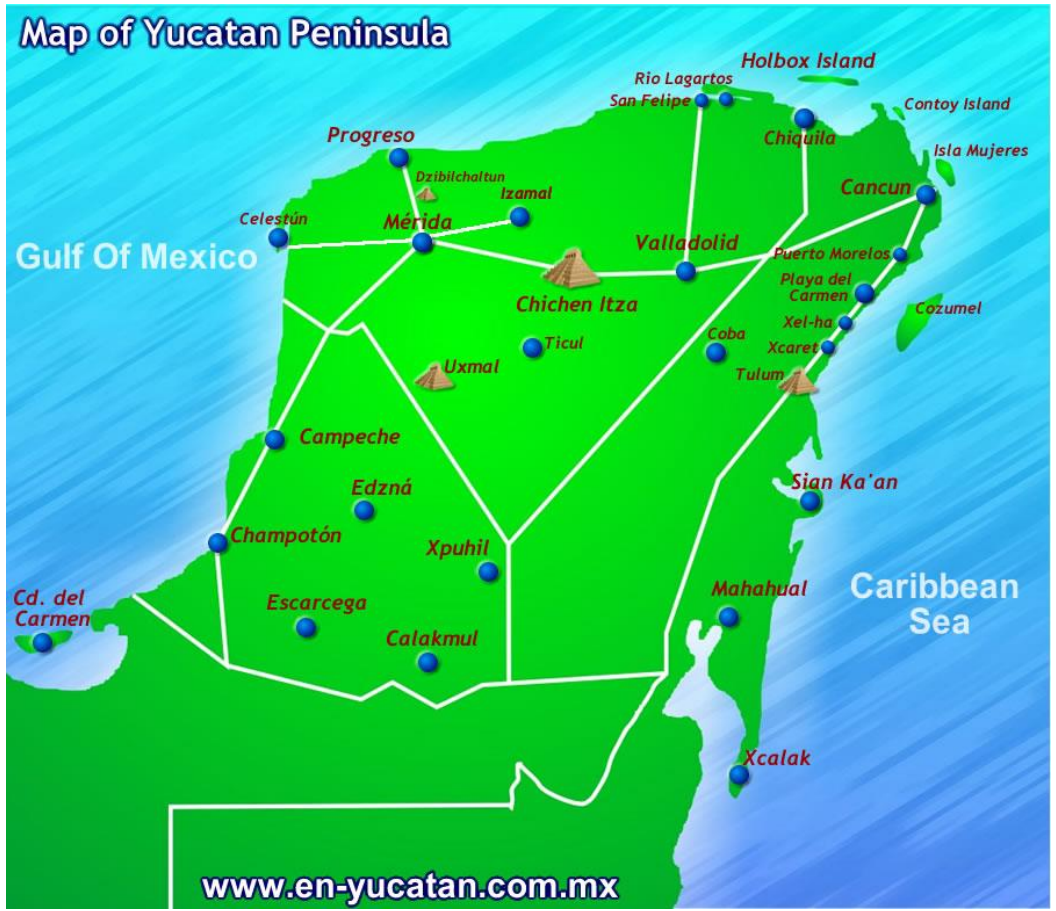

\subsection{OPERATIONAL DEFINITIONS OF THE VARIABLES}

-Cocktail shops, fishmongers, restaurants and supermarkets. Establishments that sell marine food of animal origin for human consumption and that have a health license issued by the Health Services of the state of Yucatan.

- Sea food. Any product of animal origin from the sea that provides the human body with elements for its nutrition.

—Raw marine food. Any product of animal origin from the sea that provides the human organism with elements for its nutrition and that at the time of sampling has been found in its natural state.

-Marinated sea food without heat. Any product of animal origin from the sea that provides the human body with elements for its nutrition and that at the time of sampling has been found cooked using the action of the acid of lemon juice, the acid of orange juice and vinegar.

—Sea food partially cooked with heat. Any product of animal origin from the sea that provides the human body with elements for its nutrition and that at the time of sampling has been found prepared in the following way: a) heat water to a boil; b) turn off the heat source and add the marine food; c) let the seafood "soften" in the hot water for at least $5 \mathrm{~min}$; and d) transferring the marine food to a container allowing it to stand until cool. This food is ready to be used in the preparation of ceviche and/or cocktails.

— Sea food fully cooked with heat. Any product of animal origin from the sea that provides the human body with elements for its nutrition and that at the time of sampling has been found cooked using the action of heat (grilled, fried and steam, among others). 


\subsection{TECHNIQUES AND PROCEDURES}

A first visit was made to each of the establishments specialized in the sale of seafood for human consumption and a list of 196 samples of seafood was compiled that, according to their method of preparation, were classified into raw seafood, marinated seafood no heat, partially cooked seafood with heat and fully cooked seafood with heat. The establishments received a second visit (in the period from August 1, 2017 to March 31, 2018) during which these samples were obtained. Each sample weighed approximately $50 \mathrm{~g}$; individually stored in sterile polyethylene bag (Ziploc); it was kept refrigerated; and it was sent for processing to Laboratorios Micro Clin, S.A. de C.V., from the city of Merida. The processing of the samples was carried out in the period from August 1, 2017 to March 31, 2018. For the homogenization and enrichment of each sample, as well as for the isolation and identification of the Vibrio parahaemolyticus species, we proceeded according to the methodology described in the eighth edition of the Bacteriological Analytical Manual (FDA) (Elliot et al., 1998).

-Homogenization. With the help of a sterile scalpel and a sterile anatomical forceps with a tooth, $25 \mathrm{~g}$ were weighed into a sterile Petri dish; they were transferred to a sterile $200 \mathrm{ml}$ blender glass; $125 \mathrm{ml}$ of broth peptonized with $3 \%$ sodium chloride $(\mathrm{NaCl})$ were added; and the contents were liquefied at low speed for $1 \mathrm{~min}$.

-Enrichment. One $\mathrm{ml}$ of the resulting suspension was transferred to a culture tube containing 9 $\mathrm{ml}$ of broth peptonized with $3 \% \mathrm{NaCl}$; and it was incubated at $35-37^{\circ} \mathrm{C}$ for $18-24 \mathrm{~h}$.

-Isolation. The growth on the surface was reseeded by streaks on a Thiosulfate-Citrate-Bile salts-Sucrose agar plate (TCBS agar) and on a modified Cellobiose-Polymyxin B-Colistin agar plate (mCPC agar); incubated at $35-37^{\circ} \mathrm{C}$ for $18-24 \mathrm{~h}$; from the green pigmented colonies that developed, smears were made to stain by the Gram method; when the colonies consisted of curved or slightly curved gram-negative bacilli, the oxidase test was performed as a presumptive test.

-Identification. Colonies that successfully passed the presumptive test, that is, that were positive to the oxidase test, underwent the following complementary biochemical tests: production of arginine dehydrolase; ornithine decarboxylation; decarboxylation of lysine; growth on nutrient agar with $0 \% \mathrm{NaCl}$; growth on nutrient agar with $3 \% \mathrm{NaCl}$; growth on nutrient agar with $6 \% \mathrm{NaCl}$; growth on nutrient agar with $8 \% \mathrm{NaCl}$; growth on nutrient agar with $10 \% \mathrm{NaCl}$; growth at $42^{\circ} \mathrm{C}\left(107.6^{\circ} \mathrm{F}\right)$; fermentative metabolism of sucrose; fermentative metabolism of D-cellobiose; fermentative metabolism of lactose; fermentative metabolism of arabinose; fermentative metabolism of D-mannose; fermentative metabolism of D-mannitol; hydrolysis of o-nitro- $\beta$-D-galactopyranoside (ONPG); Voges-Proskauer reaction; and gelatin liquefaction. 
Table 1 shows the differential characteristics or biochemical properties of the Vibrio parahaemolyticus species associated with clinical syndromes related to the consumption of fish and shellfish. Table 1 can also be found in various publications including Baumann \& Schubert, 1984; and Mclaughlin, 1995.

Table 1. Vibrio parahaemolyticus according to differential characteristics or biochemical properties.

\begin{tabular}{|l|c|}
\multicolumn{1}{|c|}{$\begin{array}{c}\text { Differential characteristics } \\
\text { (biochemical properties) }\end{array}$} & Vibrio parahaemolyticus \\
\hline Agar TCBS & NG \\
\hline Agar Mcpc & + \\
\hline Oxidase & + \\
\hline Production of arginine dehydrolase & + \\
\hline Ornithine decarboxylation & - \\
\hline Lysine decarboxylation & + \\
\hline Growth on nutrient agar with $0 \% \mathrm{NaCl}$ & + \\
\hline Growth on nutrient agar with $3 \% \mathrm{NaCl}$ & + \\
\hline Growth on nutrient agar with $6 \% \mathrm{NaCl}$ & - \\
\hline Growth on nutrient agar with $8 \% \mathrm{NaCl}$ & + \\
\hline Growth on nutrient agar with $10 \% \mathrm{NaCl}$ & - \\
\hline Growth at 42 ${ }^{\circ} \mathrm{C}$ (107.6 ${ }^{\circ}$ F) & $+/-$ \\
\hline Fermentative metabolism of sucrose & - \\
\hline Fermentative metabolism of D-cellobiose & + \\
\hline Fermentative metabolism of lactose & + \\
\hline Fermentative metabolism of arabinose & + \\
\hline Fermentative metabolism of D-mannose & - \\
\hline Fermentative metabolism of D-mannitol & - \\
\hline ONPG & + \\
\hline Voges-Proskauer reaction & - \\
\hline Gelatin liquefaction & \\
\hline Myo-inositol fermentation & \\
\hline V & + \\
\hline
\end{tabular}

$\mathrm{V}=$ Green pigmented colonies;

$\mathrm{NG}=$ No growth;

$+/=$ Variable

SOURCE. West et al., 1986

$2 \times 2$ contingency tables were constructed from which prevalences were calculated. The Mantel and Haenszel Chi-square statistic $\left(\mathrm{x}^{2} \mathrm{M}-\mathrm{H}\right)$ was used as a hypothesis test or test of statistical significance. The Epi Info program for Windows, version 7.1.5.2, was used to obtain the values of the $\mathrm{x}^{2} \mathrm{M}-\mathrm{H}$ statistic and the probabilities $(p)$. The criterion applied in carrying out the hypothesis tests for the difference between two percentages was based on the recommendations made by Cochran, 1954: 1 . When $\mathrm{N}>40$ use the $\mathrm{X}^{2} \mathrm{M}-\mathrm{H}$ test; 2 . When $20 \leq \mathrm{N} \leq 40$ use the $\mathrm{X}^{2} \mathrm{M}-\mathrm{H}$ test if, and only if, all expected frequencies are $\geq 5$; if in any cell there is at least an expected frequency $<5$, then use the Fisher's exact probability test (PPEF); and 3. When $\mathrm{N}<20$ use the PPEF.

$$
\mathrm{X}^{2} \mathrm{M}-\mathrm{H}=\Sigma(|\mathrm{O}-\mathrm{E}|-1 / 2)^{2} / \mathrm{E}
$$

$$
\mathrm{PPEF}=(\mathrm{A}+\mathrm{B}) !(\mathrm{C}+\mathrm{D}) !(\mathrm{A}+\mathrm{C}) !(\mathrm{B}+\mathrm{D}) \text { ! / N! A! B! C! D! }
$$


The Cornfield estimation interval was constructed at the $95 \%$ confidence level for the percentage in the population of seafood with the species Vibrio parahaemolyticus (Daniel, 1979).

$$
\mathrm{p}-\mathrm{Z} \sigma \mathrm{p} \leq \mathrm{P} \leq \mathrm{p}+\mathrm{Z} \sigma \mathrm{p}
$$

\subsection{DATA PROCESSING}

In the elaboration stage, the data were reviewed (information quality control); classified (on a qualitative scale); computerized [the Statistical Package for Social Sciences (SPSS) software for Windows, version 22] was used; presented (in tables and figures); and summarized (the corresponding summary measures were used for data classified on a qualitative scale). In the analysis and interpretation stages, the data were analyzed and interpreted, respectively.

\section{RESULTS}

One hundred ninety-six seafood samples were studied and classified according to their preparation methods into raw seafood, non-heat marinated seafood, partially heat-cooked seafood, and fully heatcooked seafood.

Table 2 presents the eight differential key tests to divide the twelve clinically significant species of the genus Vibrio into six groups. The species investigated in the present work belongs to Group 6 (negative production of arginine dehydrolase and positive decarboxylation of lysine).

Table 2. Eight differential key tests to divide the 12 clinically significant species of Vibrio species into six groups.

\begin{tabular}{|c|c|c|c|c|c|c|c|c|c|c|c|c|}
\hline \multirow[b]{2}{*}{$\begin{array}{c}\text { Pruebas clave } \\
\text { diferenciales }\end{array}$} & \multicolumn{2}{|c|}{ Group 1} & \multirow{2}{*}{ 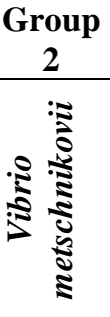 } & \multirow{2}{*}{ 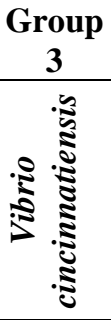 } & \multirow{2}{*}{ 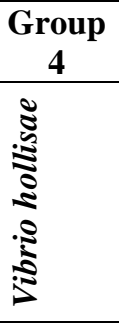 } & \multicolumn{3}{|c|}{ Group 5} & \multicolumn{4}{|c|}{ Group 6} \\
\hline & 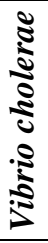 & 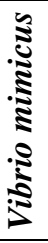 & & & & 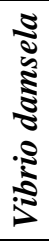 & 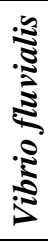 & 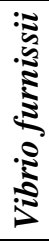 & $\begin{array}{r}5 \\
0 \\
0 \\
0 \\
0 \\
0 \\
0 \\
0 \\
0\end{array}$ & : & 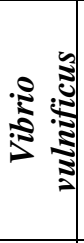 & 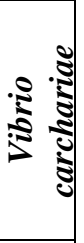 \\
\hline $\begin{array}{l}\text { Growth in } \\
\text { nutritive broth } \\
\text { with } 0 \% \mathrm{NaCl}\end{array}$ & + & + & & & & & & & & & & \\
\hline $\begin{array}{l}\text { Growth in } \\
\text { nutritive broth } \\
\text { with } 1 \% \mathrm{NaCl}\end{array}$ & + & + & & & & & & & & & & \\
\hline Oxidase test & & & - & & & & & & & & & \\
\hline $\begin{array}{l}\text { Nitrate to nitrite } \\
\text { reduction }\end{array}$ & & & - & & & & & & & & & \\
\hline $\begin{array}{l}\text { Myo-inositol } \\
\text { fermentation }\end{array}$ & & & & + & & & & & & & & \\
\hline $\begin{array}{l}\text { Production of } \\
\text { arginine } \\
\text { dehydrolase }\end{array}$ & & & & & - & + & + & + & - & - & - & - \\
\hline
\end{tabular}




\begin{tabular}{|l|l|l|l|l|l|l|l|l|l|l|l|l|}
\hline $\begin{array}{l}\text { Lysine } \\
\text { decarboxylation }\end{array}$ & & & & & - & & & & + & + & + & + \\
\hline $\begin{array}{l}\text { Ornithine } \\
\text { decarboxylation }\end{array}$ & & & & & & - & & & & & & \\
\hline
\end{tabular}

SOURCE. Kelly et al., 1991

The absolute and relative frequencies of the Vibrio parahaemolyticus species in seafood according to preparation methods are presented in Table 3.

Five $(3.36 \%)$ of the 149 samples labeled as raw seafood, $0(0.00 \%)$ of the 4 samples labeled as marinated seafood without heat, $2(5.13 \%)$ of the 39 samples labeled as partially cooked seafood with heat and $0(0.00 \%)$ of the 4 samples labeled as fully cooked seafood with heat had positive results.

The global prevalence of the Vibrio parahaemolyticus species was 3.57\% (7/196).

The Cornfield estimation interval at the $95 \%$ confidence level for the percentage in the population of seafood with the species Vibrio parahaemolyticus was: $-10.18 \% \leq \mathrm{P} \leq 17.32 \%$. Zero $(0)$ is found in this estimation interval, which agrees with the hypothesis test in the sense that there is no statistically significant difference between the percentage of raw seafood $(3.36 \%)$ and the percentage of raw seafood. partially cooked with heat $(5.13 \%)$.

Table 3. Absolute frequencies and relative frequencies of Vibrio parahaemolyticus in seafood according to preparation methods.

\begin{tabular}{|l|r|r|r|}
\hline \multirow{2}{*}{ Preparation methods } & \multicolumn{2}{|c|}{ Vibrio parahaemolyticus } & \multirow{2}{*}{ Totals } \\
\cline { 2 - 4 } & Positive samples & Negative samples & $149(100.00 \%)$ \\
\hline $\begin{array}{l}\text { Raw } \begin{array}{l}\text { Marinated without } \\
\text { heat }\end{array} \\
\begin{array}{l}\text { Partially cooked with } \\
\text { heat }\end{array}\end{array} \quad 0(3.36 \%)$ & $144(96.64 \%)$ & $4(100.00 \%)$ \\
\hline Fully cooked with heat & $2(5.13 \%)$ & $4(100.00 \%)$ & $39(100.00 \%)$ \\
\hline Totals & $0(0.00 \%)$ & $37(94.87 \%)$ & $4(100.00 \%)$ \\
\hline
\end{tabular}

\section{DISCUSSION}

The highest prevalence $(5.13 \% ; 2 / 39)$ was observed in seafood partially cooked with heat. Sea foods partially cooked with heat are those that at the time of sampling were cooked through a "softening" process in which hot water is used for at least five minutes. This result does not correspond to what was expected and the observed prevalence can be explained either because the procedure used to "soften" the food is not sufficient to destroy the microorganism - a supposition that is supported by the study by Peffers et al. (1973) in which the viability of the microorganism is reported after having kept a crustacean in boiling water for five min prior inoculation of $0.1 \mathrm{ml}$ of culture broth-, or, because the food could have been contaminated by the handler after the "softening" process due to cross contamination in the kitchens, or through the anus-hand-food mechanism because it is an asymptomatic carrier -an assumption that is 
supported by the studies of Fujino (1967), Pérez et al. (1980) and Franco \& Flores (1988) in which 0.68\% $-3.30 \%, 0.72 \%$ and $3.85 \%$, respectively, of marine food handlers who excrete the microorganism in their feces are reported.

Second is the prevalence $(3.36 \% ; 5 / 149)$ observed in raw seafood. Raw marine foods are those that were in their natural state at the time of sampling. Consequently, this result corresponds to that expected because the probability of insulation is high when the food has not been exposed to the action of heat. No statistically significant difference was found when the prevalences observed in partially cooked seafood with heat $(5.13 \%)$ and in raw seafood $(3.36 \%)$ were compared: $\mathrm{x}^{2} \mathrm{M}-\mathrm{H}(\alpha=0.0500 ; \mathrm{gl}=1)$ $<3.8416 ; p>0.0500$.

\section{CONCLUSIONS}

Raw seafood and partially heat-cooked seafood represent potential risk factors for Vibrio parahaemolyticus for the development of acute gastroenteritis, wound infection, ear infection, and secondary septicemia. Finding partially heat-cooked seafood contaminated by the species Vibrio parahaemolyticus suggests the existence of asymptomatic carrier seafood handlers. The foregoing should occupy the attention of the corresponding authorities to continue carrying out related studies in this regard. Likewise, if to date it has not been considered a public health problem, it is convenient to keep it in mind to prevent health problems that could at some point affect the health of the population of the port of Celestun, Yucatan, Mexico.

\section{ACKNOWLEDGEMENTS}

Our gratitude to the Universidad Intercultural Maya de Quintana Roo and the Yucatan Health Services for each one of the facilities provided to carry out this work. 


\section{REFERENCES}

Baumann P, Schubert RHW. 1984. Family II. Vibrionaceae, p. 516-550. In Krieg NR \&. Holt JG (eds.)., Bergey's Manual of Systematic Bacteriology, 1st ed. Williams \& Wilkins Co., Baltimore/London.

Cochran WG. 1954. Some methods for strengthening the common $\mathrm{x}^{2}$ tests. Biometrics, 10: 417-451.

Daniel WW. 1979. Bioestadística. Base para el Análisis de las Ciencias de la Salud. México, D.F.: Editorial Limusa, pp. 91-92, 143-144.

Elliot EL, Kaysner CA, Jackson L, Tamplin ML. 1998. Vibrio cholerae, Vibrio parahaemolyticus, Vibrio vulnificus, and other Vibrio spp. Chapter. 9. In Food and Drug Administration Bacteriological Analytical Manual, 8th ed. (revision A), (CD-ROM version).. Merker RL. (Ed.). AOAC International, Gaithersburg, MD.

Franco-Monsreal J, Flores-Abuxapqui JJ. 1988. Prevalencia de Vibrio parahaemolyticus en productos marinos y en heces de manipuladores de alimentos. Revista Latinoamericana de Microbiología, 30: 223227.

Fujino TT. 1967. Report of the food hygiene sub-committee on Vibrio parahaemolyticus. In: Fujino T, Fukumi H, (ed). Vibrio parahaemolyticus. Nayashoten: 673-725.

Garrity GM, Bell JA, Lilburn TG. 2004. Taxonomic Outline of the Procaryotes. Bergey's Manual of Systematic Bacteriology. pp. 1-399.

Hernández-Ávila M. 2007. Epidemiología. Diseño y Análisis de Estudios. México: Editorial Médica Panamericana.

Hernández-Sampieri R, Fernández-Collado C, Baptista-Lucio MP. 2006. Metodología de la Investigación. México: McGraw-Hill/Interamericana Editores, S.A. de C.V.

http://www.yucatan.gob.mx/?p=celestun

https://www.achipia.gob.cl/wp-content/uploads/2018/03/Ficha-Peligro-08-Vibrio-parah-v01.pdf

https://www.elsevier.es/es-revista-offarm-4-articulo-infecciones-gastrointestinales-13061801.

Kelly MT, Hickman-Brenner FW, Farmer JJ III. 1991. Vibrio: In: Balows A, Hausler WJ, Herrmann KL, Isenberg HD, Shadomy HJ (editors). Manual of Clinical Microbiology ( $8^{\mathrm{a}}$ ed.). Washington, D.C.: American Society for Microbiology, 389.

Kelly MT, Stroh MD. 1988. Temporal relationship of Vibrio parahaemolyticus in patients and the environment. Journal of Clinical Microbiology. 26(9): 1754-1756.

Mclaughlin JC. 1995. Vibrio, pp. 465-74. In: Murray PR, Baron EJ, Pfaller MA, Tenover FC, Yolken RH (eds.). Manual of Clinical Microbiology, 6th ed. ASM Press, Washington.

Pavia AT, Bryan JA, Maher KL, Hester TR Jr, Farmer JJ III. 1989. Vibrio carchariae infection after a shark bite. Annals of Internal Medicine. 111(1): 85-86. 
Peffers A, Bayley J, Barrow GI, Hobbs BC. 1973. Vibrio parahaemolyticus gastroenteritis and international air travel. Lancet. 1(7795): 143-145.

Pérez-Memije E, Vélez-González ML, Galván-Rodríguez F. 1980. Búsqueda de Vibrio parahaemolyticus en heces de manejadores de alimentos en el puerto de Acapulco, Guerrero. Revista Latinoamericana de Microbiología. 22: 18.

Shirai H, Ito H, Hirayama T, Nakamoto Y, Nakabayashi N, Kumagai K, et al 1990. Molecular epidemiologic evidence for association of thermostable direct hemolysin (TDH) and TDH-related hemolysin of Vibrio parahaemolyticus with gastroenteritis. Infect. Immun. 58: 3568-3573.

West PA, Brayton PR, Bryant TN, Colwell RR. 1986. Numerical taxonomy of vibrios isolated from aquatic environments. International Journal of Systematic and Evolutionary Microbiology. 36: 531-543.

West PA. 1989. The human pathogenic vibrios. A public health update with environmental perspectives. Epidemiology \& Infection. 103(1): 1-34. 